\title{
Tan Sitong's “Great Unity": Mental Processes and Yogācāra in An Exposition of Benevolence
}

\author{
Scott Pacey
}

Tan Sitong (1865-1898) 譚嗣同 wrote his magnum opus—Renxue 仁學 (An Exposition of Benevolence; hereafter, EOB) — in 1896 and 1897. ${ }^{1}$ It was published posthumously both in Yokohama in Qing yi bao 清議報 (China Discussion) between 1898 and 1901, as well as in Shanghai in the Yadong shibao 亞東時報 (East Asia Times). ${ }^{2}$ The work represents Tan's attempt to bring together the prominent ideas on the late Qing intellectual landscape under the rubric of Confucian ren 仁 (benevolence). Although the plurality of influences at work in EOB has been widely acknowledged, the presence of Yogācāra concepts in the book has been less extensively researched. ${ }^{3}$ This chapter will examine two ways in which Yogācāra contributed to the scheme Tan advanced in EOB. First, it will demonstrate that Yogācāra's cognitive architecture played an important role in his philosophical system alongside other theories of mind from Neo-Confucianism, science, and the Christian-based New Thought movement. Second, it will show that along with these other views, Yogācāra was central to

As a Golda Meir Postdoctoral Fellow, I gratefully acknowledge the support I have received from the Australian Friends of the Hebrew University, and the Louis Frieberg Center for East Asian Studies.

${ }^{1}$ Tan Sitong, “Renxue,” in Tan Sitong quanji 譚嗣同全集 (The Complete Works of Tan Sitong) [TSTQJ, edited by Cai Shangsi 蔡尚思, (Beijing: Zhonghua shuju, 1981), Vol. 2, pp. 289-374. The English translations in this chapter are taken from T'an Ssu-t'ung, $A n$ Exposition of Benevolence: The Jen-hsuëh of T'an Ssu-t'ung, trans. Chan Sin-wai (Hong Kong: The Chinese University Press, 1984). In the following references, Chan's translation will be indicated by "EOB," and Tan's original (in his collected works) by "TSTQJ." ${ }^{2}$ These two versions are different; the latter was included in his collected works. See Chan Sin-wai, "Introduction to 'An Exposition of Benevolence,' " in An Exposition of Benevolence, pp. 13-14.

${ }^{3}$ Erik Hammerstrom has provided a focused assessment of Tan's discussion of Yogācāra, science, and New Thought. See Erik J. Hammerstrom, "Buddhists Discuss Science in Modern China (1895-1949)" (PhD diss., Indiana University, 2010), pp. 107-121. 
Tan's utopian social project. As such, Yogācāra helped enable Tan to achieve two aims of late Qing modernizers: delineating the relationship between Chinese and Western ideas, and showing how they could be applied in ways that contributed to Chinese reform efforts.

The eclectic nature of the text is reflected in the brief reading list Tan provided at the beginning of EOB. In addition to Neo-Confucian scholars and Buddhist texts, he included such diverse entries as the writer Tao Yuanming 陶淵明 (365-427)—who penned China’s quintessential literary depiction of the ideal society, “Taohua yuanji 桃花源記” (Peach Blossom Spring) — and the New Testament. He also recommended reading scientific works. ${ }^{4}$ While his engagement with such a complex array of influences may appear unwieldy, he was conversant with many of the cutting-edge ideas of his time. Liang Qichao 梁啟超 (1873-1929) said of EOB that "while it is undeniable that it contains many inconsistent, disorderly, and childish arguments, still it broke so entirely free and independent of the fetters of the traditional thinking that it had no equal throughout the Ch'ing period." ${ }^{, 5}$ it is this novel incorporation of diverse modern and traditional ideas that has established the book's importance in Chinese intellectual history.

It is also because of Tan's pioneering use of Yogācāra in this intellectual synthesis that EOB is significant. Moreover, although later thinkers such as Taixu 太虛 (1890-1947), and as Hammerstrom shows in this volume, the Wuchang School, sought to demonstrate Yogācāra's superiority over science rather than focusing on their similarities as Tan tended to do, by dealing with science and Yogācāra in the same context, Tan helped lay the foundations for their general intellectual projects.

Tan's reading list also provides an indication of his Buddhist orientation. He mentions the foundational text of the Huayan School (Huayan zong 華嚴宗) - Avatamsaka-sūtra (Huayan jing 華嚴經; Flower Ornament Sutra) ${ }^{6}$ - as well as the Chan School (School of

\footnotetext{
${ }^{4}$ T'an, EOB, p. 65; Tan, TSTQJ, p. 293.

${ }^{5}$ Liang Ch'i-ch'ao, Intellectual Trends in the Ch'ing Period, translated by Immanuel C. Y. Hsü (Cambridge, Mass.: Harvard University Press, 1959), p. 108.

${ }^{6}$ The Huayan School, which traditionally considers Dushun 杜順 (557-640) its founding patriarch, emphasizes the interconnectivity of the phenomenal world. Huayan jing illustrates this using the image of a net with jewels (representing phenomena) in each knot. Each jewel is linked with the others through the strands of the net; each individual jewel also reflects all
} 
Mind; Xin zong 心宗) and the Faxiang School (Dharma Characteristics School; Faxiang zong 法相宗) as bearing upon the topic of benevolence. ${ }^{7}$ It is only later in EOB that he specifically mentions Cheng weishi lun 成唯識論 (Demonstration of Nothing but Consciousness) and the Dasheng qixin lun 大乘起信論 (Awakening of Mahāyāna Faith)—works of central importance in this volume. ${ }^{8}$ Tan's advocation of Huayan jing, however, and his later reference to Cheng weishi lun (both of which form part of the Faxiang textual corpus as established by Kuiji 窺基 [632-682]), indicate his partiality to Yogācāra. For many intellectuals, Dasheng qixin lun was a Yogācāra text as well. As we shall see, for Tan, the basic ideas he found in Yogācāra resonated with the other accounts of mental functioning that he encountered in the late Qing intellectual context.

\section{Intellectual background: utopia and the primacy of the mind}

EOB is a complex work, and before examining it in detail, it is prudent to first consider Tan's diverse intellectual influences and how they come together in the book. Tan wrote EOB soon after a time in which the notion of benevolence itself had undergone analysis and scrutiny. After classical scholar Yan Ruoqu 閻若璩 (1636-1704) challenged the traditional attribution of the Shang shu 尚書 (Classic of History) and the Daxue 大學 (Great Learning), other

of the other stones. The text, and the school, describes how phenomena are characterized by both unity and individuality.

${ }^{7}$ T'an, EOB, p. 64; Tan, TSTQJ, p. 293. Practitioners of Chan—or in Japanese, Zen-engage in meditation as a path to insight. The term faxiang — or "dharma characteristics" —was originally used by Huayan exegetes to denote what they saw as Yogācāra exponents' excessive attention to the external features of phenomena rather than their more fundamental, internal qualities. Despite this, it eventually became an accepted name for Yogācāra. See Charles A. Muller, “Translator's Introduction,” in Shun'ei Tagawa, Living Yogācāra: An Introduction to Consciousness-Only Buddhism, translated by A. Charles Muller (Boston: Wisdom Publications, 2009), p. xxi.

${ }^{8}$ Cheng weishi lun is Xuanzang's 玄牀 (602-664) account of Yogācāra teachings. Tradition accepts that the work is mostly based on Dharmapāla's 護法 (6th century) commentary on Vasubandhu's 世親 (4 ${ }^{\text {th }}$ century) Trimśika (Weishi sanshi lun song 唯識三十論頌; Thirty Verses). The tathägatagarbha, or matrix of buddhas, doctrine propounded in Dasheng qixin lun exerted a profound influence on East Asian Buddhism. 
evidential scholars such as Dai Zhen 戴震 (1724-1777), Jiao Xun 焦循 (1763-1820), and Ruan Yuan 阮元 (1764-1849) began to re-examine classical texts. Dai saw in Zhu Xi’s 朱喜 (1130-1200) reading of benevolence — which meant the overcoming of desire - the creation of an incorrect dualism between principle and desire. ${ }^{9}$ Ruan built on earlier philological dissections of the character for benevolence ("person," or ren 人 and "two," or er 二) to claim that it "was the fulfilment of human desires, not their denial." ${ }^{10}$ Meanwhile, Jiao emphasised the social importance of benevolence and desire, and explained that the sages had devised rituals on this basis. ${ }^{11}$

Tan followed on from these reassessments to regard benevolence through a multifaceted lens, although he deviated from Neo-Confucian understandings of the term. This can partly be ascribed to the intellectual climate in which his career unfolded, when the inherited Confucian tradition was seen as incapable of providing an impetus for progress like science and Christianity. Some, however, sought to locate a progressive dynamic within the NeoConfucian corpus of texts. Joseph Levenson shows these efforts to be epitomized in the writings of reformer and scholar Kang Youwei 康有為 (1858-1927), who in Xinxue weijing $k a o$ 新學偽經考 (On the False Classics of Xin Period Learning; 1891), Kongzi gaizhi kao 孔 子改制考 (On Confucius as a Reformer; 1897) and the Datong shu 大同書 (Book on the Great Unity), ${ }^{12}$ presented Confucianism as aligned with the modern ideal of progress. ${ }^{13}$ Kang

\footnotetext{
${ }^{9}$ Benjamin A. Elman, “The Revaluation of Benevolence (Jen) in Ch'ing Dynasty Evidential
} Research," in Cosmology, Ontology and Human Efficacy: Essays in Chinese Thought, ed. Richard J. Smith and D. W. Y. Kwok, (Honolulu: University of Hawaii Press, 1993), p. 63; Justin Tiwald, "Dai Zhen on Human Nature and Moral Cultivation," in Dao Companion to Neo-Confucian Philosophy, edited by John Makeham (New York: Springer, 2010), pp. 399422.

${ }^{10}$ Elman, "The Revaluation of Benevolence," p. 67.

${ }^{11}$ Elman, "The Revaluation of Benevolence," pp. 73-74.

${ }^{12}$ This was a work in progress when Tan was wrote $E O B$; the first two parts were published in 1913, and it was published in its entirety in 1935, after Kang's death. Although Tan learned of Kang's ideas from his students, it is apparent that he arrived at the ideas in $E O B$ independently. See Kwong, T'an Ssu-t'ung, pp. 166-168.

${ }^{13}$ Joseph Levenson, Confucian China and Its Modern Fate: A Trilogy, vol. 1 (Berkeley and Los Angeles: University of California Press, 1968), p. 81. 
explained that society would move through the stages of "disorder" and "approaching peace" to the Great Unity. ${ }^{14}$ In Datong shu he wrote that "Confucius's Era of Complete Peace and Equality, the Buddha's Lotus World, Lieh Tzu's Mount Tan P'ing, [and] Darwin's Utopia, are realities [of the future], and not empty imaginings." 15 The Great Unity was within reach; moreover, it was sufficiently similar to the utopian ideals of other systems to be mentioned alongside them. Tan also exemplified this eclectic approach.

Datong shu was published after EOB, ${ }^{16}$ and Tan did not meet Kang until 1898, although he had earlier read his Xinxue weijing kao. ${ }^{17}$ Nevertheless, both Kang and Tan operated within a common intellectual milieu—one in which Confucianism's compatibility with modernity was being articulated. In EOB, Tan therefore claimed that in the Age of Universal Peace, "with repentance, everybody can acquire the moral character of the religious founder, and can then do without the religious founder, and everybody can acquire the power of the ruler, and can then do without the ruler. At such a time, everyone can enjoy democracy everywhere." 18

His belief in Confucianism's progressive nature can also be attributed to his educational background. Tan was taught by three of Hunan's top Neo-Confucian scholars: Ouyang Zhonggu 歐陽中鵠 (1849-1911), Liu Renxi 劉人熙 (1844-1919), and Tu Qixian 涂 啟先 (1834-1900). ${ }^{19}$ All were exponents of the Neo-Confucian thought of Wang Fuzhi 王夫 之 (1619-1692) and in 1889, Tan proclaimed himself Wang's disciple. ${ }^{20}$ His own understanding of benevolence in turn bears the intellectual imprint of Wang through his teachers Ouyang, Liu, and Tu. According to Stephen Platt, Tan was particularly interested in

${ }^{14}$ Wolfgang Bauer, China and the Search for Happiness: Recurring Themes in Four Thousand Years of Chinese Cultural History, trans. Michael Shaw (New York: The Seabury Press, 1976), p. 302.

${ }^{15}$ K'ang Yu-wei, Ta T'ung Shu: The One World Philosophy of K'ang Yu-wei, trans. Laurence G. Thompson (London: George Allen \& Unwin, 1958), p. 84.

${ }^{16}$ Liang Qichao initially stated that Tan intended his book to be an elaboration of Kang's ideas, but later dropped this claim. See Kwong, T'an Ssu-T'ung, pp. 165-168.

${ }^{17}$ Ibid., pp. 125-126.

${ }^{18}$ T'an, EOB, p. 220; Tan, TSTQJ, p. 370.

${ }^{19}$ Stephen R. Platt, Provincial Patriots: The Hunanese and Modern China (Cambridge, MA; London: Harvard University Press, 2007), pp. 68-69.

${ }^{20}$ Chan, Buddhism in Late Ch'ing Political Thought, p. 59. 
Wang's Siwenlu 思問綠 (Record of Thoughts and Questions), in which Wang stressed that the "Way" needed a vessel in the world to take shape. ${ }^{21}$ Tan learned from Wang that to understand the Way, one must study the phenomenal world; a belief that found a natural corollary when he encountered science in the 1890s. ${ }^{22}$

Tan also developed Wang's views on the Way and vital stuff_ or $q i$ 氣— into "a hypothesis covering all of human society, namely, that society itself could be considered an instrument .... According to Tan's reading of Wang Fuzhi, then, to possess the latent Way, and thereby enjoy peace and prosperity, society must first be changed. ${ }^{, 23}$ China's defeat in the Sino-Japanese War (1894-95) convinced him that China was in need of reform; ${ }^{24}$ in an 1895 letter to his friend Bei Yunxin 貝允昕 (1865-1927), he advocated broad scale westernisation, and supported his view with the thought of Wang Fuzhi, stating that since there was a unity between the Way and $q i$, "when ch' $i$ changed, the Way should change accordingly.... To adopt Westernization in China was in fact to practise universal truth.",25 Tan's progressive and reformist views thus had a Neo-Confucian foundation through Wang. As we shall see below, these were bolstered with ideas from Yogācāra, lending his utopian vision a Buddhist aspect as well.

Tan would have found in Neo-Confucianism certain correlations with the Yogācāra he would encounter in the mid-1890s. In EOB, while Tan listed Wang as one of the thinkers that students of benevolence should read, he did so alongside a number of other NeoConfucians who delineated relationships between the mind, the phenomenal world and morality. Zhou Dunyi 周敦頣 (1017-1073) attributed a moral aspect to Heaven and to the Supreme Ultimate (taiji 太極) — "the source of all things in the universe" 26 - including benevolence and righteousness (yi 義). ${ }^{27}$ Zhang Zai 張載 (1020-1077) developed a form of

\footnotetext{
${ }^{21}$ Platt, Provincial Patriots, p. 73.

22 Ibid., pp. 73-74.

${ }^{23}$ Ibid., p. 73.

${ }^{24}$ Chan, "Introduction to 'An Exposition of Benevolence,'” p. 7.

${ }^{25}$ Chan, Buddhism in Late Ch'ing Political Thought, p. 64.

${ }^{26}$ Siu-chi Huang, Essentials of Neo-Confucianism: Eight Major Philosophers of the Song and Ming Periods (Westport, Conn.; London: Greenwood Press, 1999), p.32.

${ }^{27}$ Ibid., p. 26.
} 
monism in which $q i$, as the basic substance of the universe, had inherent moral qualities. ${ }^{28}$ For Lu Zijing “the universe and the mind are one.”29 Wang Yangming (王陽明; 1472-1529) held that "the mind or xin [心] and the Principle or $l i$ [理] are identical." ${ }^{, 30}$ Finally, for Hong Zongxi 黃宗羲 [Huang Lizhou 黃梨洲 1610-1695], mind was “fundamentally indeterminate substance," or qi, "and derivatively reason." 31 The Neo-Confucian figures Tan listed thus held that the basic constituent of the universe had a moral aspect, and that this was intimately linked with mind. There are parallels between this view and Tan's later equation of benevolence with the scientific concept of ether, the origin of which he traced back to Yogācāra's cognitive architecture.

Chan Sin-wai has noted that when intellectuals looked for ways to bolster Confucianism in response to Christianity and science, they "did not simply lament the fact that Confucianism was no longer practicable, but sought alternatives for the bolstering of the Chinese tradition." 32 As John Makeham notes in his introduction, while some intellectuals (Ouyang Jingwu and Lü Cheng) searched for an "original Indian Buddhism," others understood Buddhism in its received, Sinitic form. For them, Buddhism occupied a special place in this reassessment; it was a Chinese system of thought that was deemed compatible with science and superior to Western philosophy. ${ }^{33}$ Certain members of Tan's generation were thus strongly influenced by Buddhism. Kang esteemed Buddhism highly in his treatment of the Great Unity, ${ }^{34}$ and prior to 1911, Liang Qichao argued that Buddhism could "be utilized to cultivate morality for the cause of revolution, to serve as a unifying ideology and as a

${ }^{28}$ Hao Chang, Chinese Intellectuals in Crisis (Berkeley: University of California Press, 1987), p. 81. In the early 1890s, Tan studied Zhang's works. See Chan, Buddhism in Late Ch'ing Political Thought, (Hong Kong: The Chinese University Press, 1985), pp. 60-61.

${ }^{29}$ Huang, Essentials of Neo-Confucianism, pp. 173.

${ }^{30}$ Ibid., p. 194.

${ }^{31}$ Chung-Ying Cheng, "Reason, Substance, and Human Desires in Seventeenth-Century NeoConfucianism," in The Unfolding of Neo-Confucianism, edited by William Theodore de Bary, (New York: Columbia University Press, 1975), p. 497.

${ }^{32}$ Chan Sin-wai, Buddhism in Late Ch'ing Political Thought, p. 3.

${ }^{33}$ Ibid., p. 7.

${ }^{34}$ Ibid., pp. 39-40. 
philosophy which could be paralleled with Western philosophy." 35 And as Viren Murthy has written in this volume, Zhang Taiyan 章太炎 (1868-1936) used Madhyamaka and Yogācāra — and Daoist — concepts to articulate a new, revolutionary social vision in his response to global modernity.

As part of this environment in the mid-1890s, Tan delved into the study of Buddhism and-reflecting his interest in westernisation-science. In 1896 he met Liang Qichao in Beijing, ${ }^{36}$ and he subsequently discussed both topics with him and his associates in Shanghai. ${ }^{37}$ It was during this time that he also met the layman, Yang Wenhui 楊文會 (18371911). ${ }^{38}$ Yang had established the Jinling Sutra Publishing House (Jinling Kejingchu 金陵刻 經處) in 1866 in Nanjing, and, like Tan, maintained an interested in both Buddhism and science. After working in the Qing embassy in London between 1878 and 1881 (and again between 1886 and 1888), he brought a range of scientific instruments back to China. ${ }^{39}$ As John Jorgensen relates in this volume, from 1891 Yang also procured a range of Buddhist texts from Japan. ${ }^{40}$ It was after Tan's extended discussions with Yang-which included conversations on "Buddhism and Western Learning"- that he wrote EOB. ${ }^{41}$

Tan was also an avid reader of scientific works produced at the Jiangnan Arsenal by the British missionary John Fryer (1839-1928), whom he met in Shanghai in 1893 and

${ }^{35}$ Ibid., p. 42.

${ }^{36}$ See ibid., 67; Luke S. K. Kwong, T'an Ssu-T'ung, 1865-1898: Life and Thought of a Reformer (Leiden: E.J. Brill, 1996), p. 117.

${ }^{37}$ Ibid., pp. 123; 140.

${ }^{38}$ Chan, Buddhism in Late Ch'ing Political Thought, p. 69.

${ }^{39}$ Holmes Welch, The Buddhist Revival in China (Cambridge, Mass.: Harvard University Press, 1968), 4.

${ }^{40}$ Guo Peng 郭朋, Liao Zili 廖自力 and Zhang Xinying 張新鷹, "Yang Wenhui de Foxue sixiang 楊文會的佛學思想 (The Buddhist Thought of Yang Wenhui), ” in Zhongguo jindai Foxue sixiang shigao 中國近代佛學思想史稿 (A History of Recent Chinese Buddhist Thought) (Chengdu: Bachu shushe, 1989), pp. 3; 283-284.

${ }^{41}$ Zhang Hua 張華, Yang Wenhui yu Zhongguo jindai Fojiao sixiang zhuanxing 楊文會與中 國近代佛教思想轉型 (Yang Wenhui and the Transformation of Recent Chinese Buddhist Thought) (Beijing: Zongjiao wenhua chubanshe, 2004), p. 318. 
1896. ${ }^{42}$ Together, they discussed science, ${ }^{43}$ and his comments also indicate that they specifically discussed the mind. In a letter to Ouyang Zhonggu, Tan cited Fryer's claim that “there is a new method whereby we can fathom the $q i$ 氣 and nerves of a person's brain, picturing the things that are presently in [the subject's] mind, hence knowing what sort of dreams he has. [They can even] use machines to make dreams, that is to [make people] dream according to the machines . . ."44 It is clear that through Fryer, Tan would have been privy to unique views not only on the explanatory power of science, but also on its capacity to probe the mind - a key concern of the Neo-Confucianism to which he had been introduced in his youth, as well as of Buddhism.

\section{Benevolence and ether}

Tan was thus informed by an array of perspectives on the mind-Neo-Confucian, Buddhist, and scientific. In EOB, these diverse influences coalesced in his treatment of benevolence, which he explained using terms drawn from each. At the very beginning of the text, Tan wrote that "the phenomenal world, the world of the void, and the world of sentient beings are permeated with something extremely vast and minute"- the ether (yitai 以太). Ether featured prominently in nineteenth-century physics; ${ }^{45}$ by the latter part of the century it was thought to permeate the universe and serve as the vehicle for transmitting light. According to Tan,

\footnotetext{
${ }^{42}$ In 1868, Fryer had begun translating scientific works for the Chinese government at the translation department in the Jiangnan Arsenal in Shanghai. In the 1890s, he also edited Gezhi huibian 格致匯編, or Chinese Scientific Magazine.

${ }^{43}$ David Wright, Translating Science: The Transmission of Western Chemistry into Late Imperial China, 1840-1900 (Leiden; Boston; Köln: Brill, 2000), p. 124

${ }^{44}$ Tan's quotation of Fryer, cited in Wright, Translating Science, p. 124; Tan, TSTQJ, pp. 458-459.
}

${ }^{45}$ For an analysis of Tan's usage of this concept, see Wright, “Tan Sitong and the Ether Reconsidered,” pp. 558-563. On ether theories more generally, see Wang Xiwei 王錫偉, “Lun 'yitai' shuo de xiandai renshilun yiyi 論 '以太' 說的現代認識論意義 (On the Meaning of Ether Theory for Modern Epistemology)," Jiangsu shehui kexue 2 (2007): pp. 36-38. 
however, ether (like benevolence) was produced by the mind, ${ }^{46}$ and it was therefore to be equated with the eight consciousnesses of Yogācāra. ${ }^{47}$

Tan would have found support for the importance of ether and its relationship to the mind in a book by Henry Wood entitled Ideal Suggestion Through Mental Photography, which John Fryer translated as Zhixin mianbingfa 治心免病法 in 1896. Wood stated that ether conveyed thought, and Fryer added, in his translation, that

recently, Western countries have discovered that the myriad things have in them a circulating quality called "ether." Even inside the farthest star there cannot be a vacuum; it must be filled with this "ether." This "ether" is even in the particles of the terrestrial atmosphere. . . No matter where or what it is, it cannot be avoided. Without ether, light from the sun and planets would not reach the Earth's surface . . . Thoughts are transmitted according to the same principle. Regardless of the distance, or whether the five senses can perceive it, when one is moved to emit a thought, ether will channel it to the minds of others. ${ }^{48}$

\footnotetext{
${ }^{46}$ Chan, "Introduction to 'An Exposition of Benevolence,', p.18.

${ }^{47}$ Ibid., 23-24.

${ }^{48}$ Fryer, cited in Zou Zhenhuan 鄒振環, Yingxiang Zhongguo jindai shehui de yibai zhong yizuo 影響中國近代社會的一百種譯作 (One Hundred Translations that Influenced Modern Chinese Society) (Beijing: Zhongguo duiwai fanyi chuban gongsi, 1996), p. 108. For a different translation, see Shek, "Some Western Influences," p. 568. Wood mentions ether on page 52: "We find that the great force called thought has scientific relations, correlations, and transmutations; that its vibrations project themselves in waves through the ether, regardless of distance and other sensuous limitations; that they strike unisons in other minds and make them vibrant; that they relate themselves to like and are repelled by the unlike; that their silent though forceful impact makes a distinct impression; in fact, that they are substantial entities, in comparison with which gold, silver, and iron are as evanescent as the morning dew." See Wood, Ideal Suggestion, 52. Zou suggests that Wood's book is a possible source for his particular conception of ether, along with Pictorial Explanations of Optics (Guangxue tushuo 光學圖説) — another of Fryer's translations, which was published in 1890. See Zou, Yingxiang Zhongguo, pp. 109-112.
} 
The ether-benevolence construct was not only produced by the mind, ${ }^{49}$ it was "a manifestation of the consciousness of the entire universe, connecting the physical, mental, and spiritual realms." ${ }^{, 50}$ It also served a metaphysical function, holding together matter and astral bodies, familial and social relationships, and the Buddhist conception of the cosmos. ${ }^{51}$ Using Yogācāra terminology, Tan explained that while all things in the universe came from benevolence, "benevolence is the source of heaven, earth, and the myriad things: thus there is nothing but mind [wei xin 唯心]; thus there is nothing but consciousness [weishi 唯諳]. ${ }^{, 52}$ As "an object projected by nothing but consciousness," Benevolence therefore united nineteenth-century physics, the Neo-Confucian understanding of $q i$ as having a moral aspect, and Yogācāra's emphasis on cognitive experience.

\section{Neurophysiology}

In EOB, Tan also sought to show how Yogācāra's eight consciousnesses cohered with scientific knowledge about the brain. ${ }^{55}$ The period of Tan's career had seen remarkable advances in the fields of biology and brain science. ${ }^{56}$ In his chapter in this volume, Hammerstrom notes Gustav Fritsch (1837-1927) and Eduard Hitzig's (1839-1907) discoveries linking brain function, movement, and electricity. Early in the nineteenth century, Charles Bell (1774-1842) and François Magendie (1783-1855) determined that electrical signals were sent from peripheral nerves to muscles, and from sense organs to the central nervous system. Nobel Prize winner Ramón y Cajal (1852-1934) made discoveries about the structure of nerve cells, and that signals were conveyed between them. ${ }^{57}$ Meanwhile, in 1875 ,

${ }^{49}$ Chan, "Introduction to 'An Exposition of Benevolence,'” p. 24.

${ }^{50}$ David Wright, "Tan Sitong and the Ether Reconsidered," Bulletin of the School of Oriental and African Studies 57:3 (1994), p. 556.

${ }^{51}$ T'an, EOB, 68; Tan, TSTQJ, p. 294.

${ }^{52}$ T'an, EOB, 62; Tan, TSTQJ, p. 292.

${ }^{53}$ See Chan, Chan, Buddhism in Late Ch'ing Political Thought, p. 93; T'an, EOB, p. 136; Tan, TSTQJ, p. 331.

${ }^{54}$ See also Chan, Buddhism in Late Ch'ing Political Thought, p. 87.

${ }^{55}$ As John Jorgensen notes, Hara Tanzan had already linked the brain and spine to the consciousnesses of Yogācāra in Japan in 1870.

${ }^{56}$ See chapter 4 of J. Allan Hobson, The Dreaming Brain (New York: Basic Books, 1988).

${ }^{57}$ Ibid., p. 95. 
Richard Caton measured the first EEG signals. ${ }^{58}$ The work of nineteenth-century researchers led to the view that

brain function is electrically mediated. Each nerve cell is a sophisticated electrical element capable of generating a resting potential and of rapidly changing that potential through a reversal of its intrinsic membrane charges. These action potentials constitute a continuous stream of signals flowing through the vast system of neurons that is our brain. Somehow the stream of electrical signals is related to the stream of what we call consciousness. ${ }^{59}$

Reflecting this state of knowledge, Tan equated the brain itself with electricity. ${ }^{60} \mathrm{He}$ explained that the nervous system was like a series of wires,${ }^{61}$ and that thoughts produced movement in brain nerves and had unique electrical outputs. But he also identified Yogācāra's eight consciousnesses with the cerebrum and the cerebellum. ${ }^{62}$ Accordingly, the cerebrum had both a "substance" ( $t i$ 體), which was the eighth, or base consciousness, and a “function” (yong 用), which was Yogācāra's sixth, thinking consciousness. ${ }^{63}$ The cerebellum, too, had both a substance (the seventh, evaluating consciousness, or manas), and a function

${ }^{58}$ Ibid., p. 100.

${ }^{59}$ Ibid., 108.

${ }^{60}$ T'an, EOB, 69: Tan, TSTQJ, p. 295.

${ }^{61}$ T'an, EOB, 73; TSTQJ, p. 295.

${ }^{62}$ Tan thus ascribed spiritual functions to anatomical structures of the brain, as Descartes had done when asserting that the pineal gland was the repository for the soul. I am grateful to Dan Lusthaus for this observation. For Descartes' theory compared to those of his predecessors and contemporaries see Gert-Jan C. Lokhorst and Timo T. Kaitaro, "The Originality of Descartes Theory about the Pineal Gland," Journal of the History of the Neurosciences 10:1 (2001): pp. 6-18.

${ }^{63}$ Digital Dictionary of Buddhism, $<$ http://buddhism-dict.net/ddb>, entry on yishi 意諳; accessed February 29 2012, (article by C. Muller), internet. 
(the sense consciousnesses). ${ }^{64}$ Tan thus provided an answer to the unexplained relationship between electricity and consciousness by combining discoveries about the brain's electrical functions with Yogācāra's cognitive architecture.

A likely source for some of Tan's information of the brain may have been a series of school textbooks translated and published by John Fryer at the Jiangnan Arsenal. These were written from the perspective of Scientific Temperance Instruction, which held that alcohol was a form of poison and the cause of illness. The books, however, also contain much information on human biology. ${ }^{65}$ Tan referred to the brain's physical structure when he subsumed a physical explanation of the visual system within the broader context of Yogācāra, explaining that "the circular cavity in front of the cerebrum is a mirror in which is reflected all the images of heaven, earth, and the myriad things. ${ }^{, 66}$ He thus connected the operation of the visual consciousness to a specific point in the skull.

Tan also relied on Yogācāra's cognitive model when explaining topics that fell within the purview of the then-new discipline of psychology, including how we dream, the cause of insanity, and how we could achieve benevolent interconnections with others. He wrote that dreams and insanity arose when the thinking consciousness (the sixth) was connected, but the ego-centered consciousness (the seventh) was only partially connected. Tan apparently meant that the seventh consciousness was partially_although not completely_ “cut off” (duanjin 㫁盡) from the base consciousness, thus depriving it of data used in cognition. This resulted in the continued belief in the existence of the self, but a disbelief in the existence of dharmas. Tan wrote of such individuals that "their cerebrum is still conscious, while their cerebellum is semi-conscious."

${ }^{64}$ T'an, EOB, p. 209; Tan, TSTQJ, 364. See Digital Dictionary of Buddhism, $<$ http://buddhism-dict.net/ddb>, entry on siliangshi 思量識; accessed June 03 2012, (article by C. Muller), internet.

${ }^{65}$ These are: Haitong weisheng bian 孩童衛生編 (Health for Little Folks; 1894), Youtong weisheng bian 幼童衛生編 (Lessons in Hygiene; 1895) and Chuxue weisheng bian 初學衛生 編 (First Book in Physiology and Hygiene; 1896). See Ruth Rogaski, Hygienic Modernity: Meanings of Health and Disease in Treaty-Port China (Berkeley and Los Angeles: University of California Press, 2004), pp. 118-120.

${ }^{66}$ T'an, EOB, 135; Tan, TSTQJ, p. 331.

${ }^{67}$ T'an, EOB, 210; Tan, TSTQJ, p. 364. 
To understand why Tan felt this was important, we may consider that dreams and insanity were interlinked in late nineteenth-century psychology, when "dreaming was seen as capable of inducing both hysterical paralysis and paranoia; and vice versa, psychosis was seen as a breakthrough of the dream process. Thus many pre-Freudian authors regarded the dream as nocturnal insanity." ${ }^{, 68}$ Tan dealt with this dual concern of nineteenth-century psychology with reference to Yogācāra's cognitive processes. He explained that data received by the five sense consciousnesses was channeled to the cerebrum (which housed the base consciousness), while the cerebellum (which embodied the function of the five sensory consciousnesses and the evaluating consciousness) created dreams on the basis of this information. He added that the evaluating consciousness of children was not fully formed, and therefore they did not dream. Meanwhile, the Daoist “perfect man” (zhiren 至人) also did not dream, but for a different reason: data from the sense consciousnesses did not "ferment," meaning that dreams would not arise. ${ }^{69}$

The idea that fools and sages did not dream is frequently referenced in Chinese literature and philosophy. ${ }^{70}$ Zhuangzi states that "True Men [zhenren 真人] of old slept without dreaming and woke without cares." ${ }^{, 71}$ Tan's views on dreams and insanity, however, also reflect contemporary physiological understandings of the brain. For scientists of this period, "insanity was a disease of the brain,"72 and dreams had physical causes. Johannes Müller (1801-1858) suggested that dreams resulted from bodily movements; Wilhelm Wundt (1832-1920) and Alfred Maury (1817-1892) proposed they arose from internal and external bodily sensations. George Trumbull Ladd (1842-1921), Joseph Delboeuf (1831-1896), Karl

\footnotetext{
${ }^{68}$ Hobson, The Dreaming Brain, p. 51.

${ }^{69}$ T'an, EOB, 210; Tan, TSTQJ, p. 365.
}

${ }^{70} \mathrm{See}$, for example, two articles that appeared in Shenbao 申報 in the years preceding Tan's composition of $E O B$ : Author unknown, “Meng yuan xiao ji 夢緣小記 (Notes on the Reasons for Dreams), Shenbao 5989 (Dec. 19 1889); author unknown, “Shuo meng 說夢 (On Dreams)," Shenbao (Shanghai Journal) 6018 (Jan. 17 1890).

${ }^{71}$ Graham, A. C., trans. Chuang-tzŭ: The Seven Inner Chapters and Other Writings (London: Unwin Paperbacks, 1986), 84.

${ }^{72}$ William Wingfield, "The Asylum: Its Construction and Deconstruction," in Psychotropic Drugs and Popular Culture: Essays on Medicine, Mental Health and the Media, edited by Lawrence C. Rubin (Jefferson, N.C.: McFarland, 2006), p. 26. 
Scherner (1825-1889) and Karl Binz (1832-1913) also put forward physiological theories of dreams. $^{73}$

It is difficult to determine precisely where, and if, Tan had been exposed to such theories. As mentioned above, he reported that he had discussed dreams and the mind with John Fryer. However, these physiological accounts were also part of a general discourse concerning these subjects. An article appearing in an 1888 issue of The Century, for example, provided an overview of dream research, and stated that "there is no proof that babies dream at all. ... The condition of the babe in sleep is precisely such as might be expected from its destitution of recorded sensations. ${ }^{, 74}$ An 1897 piece appearing in the magazine Zhi xin bao 知新報 (The Reformer China) reported on an article appearing in the Scientific American Supplement, which concluded that dreams are constructed from sensations and memories. The Chinese article added that "thus children have few dreams, and elderly people have many dreams." ${ }^{, 75}$

Tan was concerned not only with showing the concordance between Yogācāra and science. He also equated concepts in the Great Learning - a key text in Neo-Confucianismwith Yogācāra's cognitive system:

$[w]$ hen the first five kinds of consciousness are transmuted into the Wisdom of Perfect Achievement [cognition with unrestricted activity; ${ }^{76}$ cheng suozuo zhi 成所作 智], this is what the Great Learning means when it says, “Cultivate the person and the

${ }^{73}$ See Hobson, The Dreaming Brain, pp. 23-51.

${ }^{74}$ J. M. Buckley, "Dreams, Nightmare, and Somnambulism," The Century 36:3 (Jul. 1888): p. 448.

75 Author unknown, “Mengli jingshuo 夢理精說 (A Discussion of Dream Principles), Zhi xin bao 28 (1897): p. 25. The article refers to a piece appearing in a June 19 issue of Scientific American Supplement. See: Author unknown, "The Theory of Dreams," Scientific American Supplement 1120 (June 19, 1897): pp. 17909-17910. This article, in turn, takes its information from “The Theory of Dreams," Literary Digest 14:10 (Jan. 9 1897): p. 303, which is the translation of a piece that appeared the previous year in the French journal Cosmos. See L. Ménard, “La Théorie des Rêves,” Cosmos 619 (Dec. 5 1896): pp. 585-586. ${ }^{76}$ Digital Dictionary of Buddhism, $<$ http://buddhism-dict.net/ddb>, entry on cheng suo zuo zhi 成所作智; accessed February 21 2012, (article by C. Muller), internet. 
person is cultivated." The so-called eyes, ears, nose, tongue and body in Buddhism are collectively called the 'person' in Confucianism. When Confucius told Yen Hui of the "four dont's," he spoke with due reference to the rites that Yen Hui should observe when he looked, listened, spoke, or moved. Such straight-forward remarks show that the store-consciousness [base consciousness; zangshi 藏識] of Yen had already been transmuted into wisdom. Only when the transmutation of one's store consciousness [base consciousness] has been achieved can one be benevolent. ${ }^{77}$

For Tan, there were clearly no impediments to identifying correlations between the major features of his intellectual world. Regardless of the exact sources of his knowledge, he thus combined nineteenth-century physiology with Confucian, Daoist and Buddhist elements to present a novel understanding of how the mind worked.

\section{New Thought}

Alongside Neo-Confucianism and Yogācāra, New Thought provided another theory of mental processes that informed Tan's conception of mind in EOB. Reflecting his concern for China's future after its 1895 defeat in the Sino-Japanese War, Tan felt that China was suffering the results of negative karma accrued by generations of tyrannical rulers, ${ }^{78}$ and that this would result in the devolution of the Chinese people. ${ }^{79}$ Changing this course was again a question of mental reformation; he remarked that since a "kalpa destiny is created by the mind, it certainly can be resolved by it too." 80 This could be achieved by turning to Buddhism, or the ideas of the afore-mentioned Henry Wood $^{81}$ - a central figure in the New Thought movement then popular in the United States. As noted above, Tan had read John Fryer's

\footnotetext{
${ }^{77}$ T'an, EOB, 138; Tan, TSTQJ, p. 332.

${ }^{78}$ T'an, EOB, 193; Tan, TSTQJ, p. 356. Citing this section of Tan's text, Geremie Barmé situates him in a lineage of pessimistic thinkers leading up to 1980s PRC intellectuals. See Geremie R. Barmé, “To Screw Foreigners is Patriotic: China’s Avant Garde Nationalists,” The China Journal 34 (Jul., 1995): pp. 209-234.

${ }^{79}$ T'an, EOB, 167; Tan, TSTQJ, p. 344.

${ }^{80}$ T'an, EOB, 194; Tan, TSTQJ, p. 356. A kalpa is the length of time between universes in the cosmic cycle of creation and destruction.

${ }^{81}$ T'an, EOB, 195-96; Tan, TSTQJ, p. 357.
} 
translation of Wood's Ideal Suggestion Through Mental Photography after it was published in 1896.

Alongside New Confucianism and Yogācāra, New Thought provided another theory of mental processes that informed Tan's conception of mind in EOB. Like Scientific Temperance Instruction, New Thought was concerned with the root cause of illness, however, New Thought held this to be incorrect modes of thinking rather than alcohol. The movement emerged from an environment in which various forms of mental healing - the early progenitor of which was Phineas Pankhurst Quimby, a practitioner of "mental therapeutics" $" 82$ - were being popularised. Quimby held that disease arose in the mind, and that physical cures could be enacted through psychological therapy. ${ }^{83}$ Wood's book was one of a number of publications which, in the 1890 s, helped mental healing techniques attain widespread popularity. ${ }^{84}$

According to Dell deChant, "New Thought's primary beliefs are idealistic in character"; ${ }^{85}$ it holds that the "universe is mental," and "all material-physical phenomena result from one's mental states." ${ }^{, 86}$ Wood himself wrote:

God made man a "living soul," and therefore he is a soul, not has a soul. His body is a temporary material correspondence; a set of instruments for his convenience on the plane of sense. . . Just behind the seen and material human organism there is a sensuous mind, the most outer and fleshly of the immaterial part, which pertains especially to the body and acts directly upon it. Next within is the intellectual zone,

\footnotetext{
${ }^{82}$ Eva S. Moskowitz, In Therapy We Trust: America's Obsession with Self-Fulfillment (Baltimore: The Johns Hopkins University Press), p. 11.

${ }^{83}$ Ibid., pp. 10-18.

${ }^{84}$ Moskowitz, In Therapy We Trust, p. 18. On this aspect of New Thought, see Eva Moskowitz, "The Therapeutic Gospel: Religious Medicine and the Birth of Pop Psychology, 1850-1910," Prospects 20 (1995): pp. 57-86.

${ }^{85}$ Dell deChant, "The American New Thought Movement," in Introduction to New and Alternative Religions in America, vol. 3, edited by Eugene V. Gallagher and W. Michael Ashcraft, 67-91 (Westport, Conn.: Greenwood Press, 2006), p. 81.

${ }^{86}$ deChant, "The American New Thought Movement," p. 82.
} 
and still deeper, in the innermost, is the spiritual ego, the divine image. This is the Christ-plane, where dwells the perfect humanity. ${ }^{87}$

Wood outlined a method of spiritual practice, explaining that ultimately "the physical organism is only the soul made manifest," 88 and that "the practical universe to each one is that which is built of thoughts, mental states, and delineations." ${ }^{89} \mathrm{He}$ advocated a process of moving one's ego up the planes of consciousness to the highest level - that of the "Christplane," to realize that reality was an emanation of God. In this transcendental scheme, the "soul must rise superior to environment, dominate body, and free itself from degrading and long-continued servitude." 90

A key part of the required cultivational practice involved meditating on certain statements that were printed on separate pages in the second part of the book. Examples include: "I am soul," "spirit is the only substance" and "I am not body." It is not difficult to see how intellectuals with an interest in Buddhism in the late Qing would have been receptive to Wood's ideas. According to Kay Alexander, New Thought arose "within self-consciously Christian circles," but it "developed nationwide against a background of wider interest in comparative religions," 91 including Buddhism. ${ }^{92}$ New Thought certainly resonates with possible idealistic trends in Yogācāra texts. As John Powers explains in this volume, this is exemplified by the third century text Samdhinirmocana-sūtra (Jie shenmi jing 解深密經; Discourse Explaining the Thought), in which the Buddha states that objects of perception and

${ }^{87}$ Henry Wood, Ideal Suggestion Through Mental Photography: A Restorative System for Home and Private Use; Preceded by a Study of the Laws of Mental Healing (Sixth ed., Boston: Lee and Shepard Publishers, 1893), p. 33. For the Chinese translation, see Wute Hengli 烏特亨利 [Henry Wood], Zhixin mianbingfa: er juan 治心免病法: 二卷, translated by Fu Lanya 傅蘭雅 [John Fryer] (Shanghai: Gezhi shushi kanben, 1896).

${ }^{88}$ Wood, Mental Photography, p. 72.

${ }^{89}$ Ibid., p. 84.

${ }^{90}$ Ibid., p. 86.

${ }^{91}$ Kay Alexander, "Roots of the New Age," in Perspectives on the New Age, edited by James R. Lewis and Gordon Melton, 30-47 (Albany: State University of New York Press, 1992), p. 35.

${ }^{92}$ Ibid., 36. 
cognition are the same. Wood's ideas on mental purification also correspond, superficially, with the practical aims of Yogācāra.

There are also parallels between New Thought's assertion that there is an essential, pure nature internal to the self, and the Buddhist tathatagagarbha (rulaizang 如來藏; matrix of the buddhas) as discussed in popular Buddhist texts such as Desheng qixin lun (Awakening of Mahāyāna Faith) and the Lañkāvatāra-sūtra (Lengqie jing 楞伽經; Discourse on [the Buddha's] Entering [the Country of] Lanka), where it was a pure, undefiled inner nature that exists in sentient beings and which will be revealed when delusion is cast aside. Of course, New Thought and Yogācāra are fundamentally different, and juxtaposing them in the scholarly arena is rightly questionable (at best). In the context of the late Qing, however, finding correlations between Chinese and Western thought was a key concern of reformoriented intellectuals. Identification of a common truth underlying both lent legitimacy to Sinitic ideas and served to reify their value. There was clearly much in these two philosophies for them to work with.

Chang Hao considers "Mahayana Buddhism and Confucianism" to have been more important "in articulating [Tan's] belief in the spiritual power of the human mind" than New Thought. ${ }^{93}$ Wood's influence, however, might be detected in Tan's views on how science and technology could enable us to decrease our dependency on the physical body. According to Tan, human physiology could be altered so it could sustain itself solely from the atmosphere-like the Daoist practice of "swallowing air." "94 A method might be invented that would reduce the heavy, physical particles of the body, ${ }^{95}$ so that humans became only "wisdom and soul," which could possibly be achieved through eugenics. ${ }^{96}$ Whereas "soul is an attribute of wisdom; body is an attribute of karma consciousness"; however "with equality,

\footnotetext{
${ }^{93}$ Chang, Chinese Intellectuals in Crisis, p. 84.

94 The prominent Taiwanese monastic, Xingyun expressed similar views in 2001. See Xingyun 星雲, “Renjian Fojiao de lantu (er) 人間佛教的藍圖 (二) (A Blueprint for Buddhism in the Human World (II),”Pumen xuebao 普門學報 (Universal Gate Buddhist Journal) 6 (Nov., 2001), p. 24.

95 T'an, EOB, 213; Tan, TSTQJ, p. 366.

96 T'an, EOB, 213; Tan, TSTQJ, p. 366.
} 
body can become soul."97 Tan's emphasis on the primacy of mind, as reflected in NeoConfucianism, Sinitic understandings of Yogācāra influenced by Dasheng qixin lun, and New Thought, led to him considering that the body may well be transcended altogether. ${ }^{98}$

\section{Yogācāra and utopia in EOB}

Kwong notes that in EOB, "a perfect society was possible because of the supposed, transformative efficacy of mental power (a lá Henry Wood via Fryer)." 99 This human transcendence of the physical brings us to the final part of EOB in which Yogācāra, along with the various influences mentioned above, played a role: its utopian social project.

In an influential study, Krishan Kumar argues that three factors distinguish utopianism from other conceptions of the ideal life: its emphasis on science, the notion that utopias could exist in time, and the idea of progress - that utopia could be actualized in the future. ${ }^{100}$ Utopianism was secular and humanistic, and embodied a belief that "there is nothing in man, nature, or society that cannot be so ordered as to bring about a more or less permanent state of material plenty, social harmony and material fulfillment."101 This meant that non-Western conceptions of the ideal society were not true utopias; Chinese ideal states such as the Confucian Great Unity were "backward-looking ideological slogans" that were

\footnotetext{
${ }^{97}$ T'an, EOB, 62. Tan, TSTQJ, p. 291. Tan was, however, critical of "the Western concept of soul," and what he claimed was the ascription of souls only to human beings. See T'an, EOB, p. 95; Tan, TSTQJ, p. 310. On Jewish, Christian and Islamic perspectives on animals, see G. H. Bousquet, "Des Animaux et de leur traitement selon le Judaïsme, le Christianisme et l'Islam (Animals and Their Treatment According to Judaism, Christianity and Islam)," Studia Islamica 9 (1958): pp. 31-48. Bousquet finds evidence in the OT and Talmud suggesting that animals are similar to humans and thus have souls. The NT, on the other hand, has much less to say about animals. I thank Dan Lusthaus for drawing my attention to this issue.

${ }^{98}$ However, the question as to whether Tan was ultimately a materialist or idealist is difficult to resolve conclusively, and was taken up with vigor by Marxist writers in China after TSTQJ's publication in 1954. For an account of this debate, see Chan, "Introduction to 'An Exposition of Benevolence,'” pp. 25-34.

${ }^{99}$ Kwong, T'an Ssu-T'ung, p. 159.

${ }^{100}$ Krishan Kumar, Utopianism (Milton Keynes: Open University Press, 1991).

${ }^{101}$ Ibid., p. 29
} 
"based on their vision of the good life." 102 As a result, only through an exposure to the West in the nineteenth century did China develop true utopian schemes, such as Kang Youwei's Datong shu and the social ideals of the Taiping Rebellion. ${ }^{103}$ In a similar vein, in his study of Tan's thought, Chang Hao asserted that the "transcendental and ahistorical" nature of EOB "militate against the view of history as a temporal process directed toward the future.",104 Thus, EOB “does not issue (as K’ang Yu-wei’s philosophy did) in any futuristic utopianism."105

However, EOB can be considered utopian in some important ways. Tan clearly advocated the use of science and technology, particularly to augment human development. He also had a conception of progress, both in terms of human evolution, as well as the ideal future society. Both of these visions were ultimately Buddhist in nature, and depended on human action for their realization. Tan described this society as it would be when Amitābha was present on earth: "People will then be well provided for and happy, mountains and rivers will look like mirrors, thusness [Suchness] will prevail in the dharma realm, and the people will have attained Buddhahood, while those who have not will surely attain it when the earth is about to be destroyed, if not at the time when the world enjoys great prosperity."106 While these social conditions recall the Pure Lands of Buddhist cosmology_-Tan advocated their recreation on earth through science, and a form of individual cultivation he found support for in Neo-Confucianism, New Thought and Yogācāra. This would create a world in which "all the people will have universally attained Buddhahood." ${ }^{\text {107 }}$ Reflecting further influences from the West, Tan noted that this future society would be akin to the one described in Edward Bellamy's best-selling 1888 novel Looking Backward: $2000-1887,{ }^{108}$ which told the story of

\footnotetext{
102 Ibid., p. 34.

${ }^{103}$ Ibid., pp. 34-35.

${ }^{104}$ Chang, Chinese Intellectuals in Crisis, p. 103.

105 Ibid.

${ }^{106}$ T'an, EOB, 214; Tan, TSTQJ, p. 367.

${ }^{107}$ T'an, EOB, 220-221; Tan, TSTQJ, p. 370.
}

${ }^{108}$ Hammerstrom notes the importance of this book as an example of futuristic sciencefiction in the late Qing. See "Buddhists Discuss Science," pp. 96-97. A translation by the Welsh missionary Timothy Richard was published in Wanguo gongbao 萬國公報 (The Globe Magazine) in 1891 and 1892. See Martin Bernal, Chinese Socialism to 1907 (Ithaca, N.Y.: Cornell University Press, 1976), p. 22. In his translation of EOB, Chan suggests that in 
a Boston man who fell into a trance and awoke in 2000 amidst a socialist utopia. However, Tan established mental processes as the most important driver of the historical process; since he advocated mental reformation as the way to avoid the terrible consequences of China's karmic burden and move toward a brighter future.

the relevant passage, Tan was referring to the story of Rip van Winkle (p. 217, n. 392). According to Guo Yanli, the editors of the earlier 1981 edition of Tan Sitong quanji likewise did not identify the characters “bainian yi jue” 百年一覺 (“waking after a hundred years”) as the title of a book, and understood Tan as referring to Rip van Winkle, the story of which was published in the Shenbao in 1872 as “Yi shui qishi nian一睡七十年” (A Seventy-Year Slumber). However, the title of Bellamy's novel, Looking Backward, was in fact translated by Timothy Richard as Bainian yi jue 百年一覺 and published in 1894. See Guo Yanli 郭延 禮, Wenxue jingdian de fanyi yu jiedu: Xifang xianzhe de wenhua zhi lü 文學經典的翻譯與 解讀: 西方先哲的文化之旅 (The Explanation and Translation of Literary Classics: The Cultural Travels of Past Western Thinkers) (Jinan: Shandong jiaoyu chubanshe, 2007), pp. 280-282. In 1891 and 1892, Richard's translation had also been serialized in Wanguo gongbao under the title Huitou kan jilüe 回頭看紀略 (Looking Backward). In Huitou kan jilüe, however, Richard saw the blueprint for a future Chinese society. He imbued the book with a stronger Christian message than that of the original, inserting a passage at the end about Christian forgiveness. In the original, Julian West kneels beside his love (Edith), and "confessed with tears how little was my worth to breathe the air of this golden century, and how infinitely less to wear upon my breast its consummate flower. Fortunate is he who, with a case so desperate as mine, finds a judge so merciful." See Edward Bellamy, Looking Backward, 2000-1887 (Cambridge, MA: Belknap Press of Harvard University Press, 1967), 311. According to Liu Shulin, in Richard's translation, West "then said 'Never before have I harboured a desire to be of aid to the world. Now, I was not at first qualified to live in this world. But I have already promised heaven that having arrived here, I will completely change; I desire to benefit people.' Edith said, 'God is supremely merciful. After repenting for one's past sins, one is forgiven.' With this, West became peaceful" (p. 132). However, Liu expresses doubt that this Christian message was influential on Tan. See Liu Shulin 劉樹林, “Li Timotai yu ‘Huitou kan ji lüe’ 李提摩太與《回頭看紀略》:中譯美國小說的起源 (Timothy Richard and 'Looking Backward': The Origin of the Chinese Translation of American Novels)," Meiguo yanjiu 1 (1999): pp. 122-138. 


\section{Conclusion}

Both Tan and EOB continued to exert an influence long after his death. Zhang Kundi 張昆弟 (1894-1932) recalled that in 1917, in a meeting with Mao Zedong 毛澤東 (1893-1976) and Cai Hesen 蔡和森 (1895-1931), Mao opined that China needed a thinker like Tolstoy to clear away old modes of thinking and proclaimed that "before there was Tan Sitong; now there is Chen Duxiu [陳獨秀; 1879-1942]. Their spirits are great—something that, to be honest, conventional studies (suxue 俗學) cannot equal." ${ }^{109}$ After the publication of Tan Sitong quanji in 1954, EOB also played a role in the materialism versus idealism debate. Tan's attempts to link Yogācāra's cognitive architecture to the brain's physiology, in a sense, was also a precursor to contemporary neuroscientific studies of Buddhist meditation, in which scientific and Buddhist concepts enter into a mutually supportive relationship. ${ }^{110}$ His attempt to find common features between Buddhism and science also prefigured the approach of both Taixu and the Wuchang School, while his hopes for an ideal society were a precursor to Taixu's “Pure Land in the human world” (renjian jingtu 人間淨土): the vision of a society guided by Buddhism.

Hammerstrom notes that after EOB's publication, Buddhists did not continue to engage with ether - the concept had become untenable after the theory of relativity's

${ }^{109}$ Mao Zedong 毛澤東, Mao Zedong zaoqi wengao 1912.6-1920.11 毛澤東早期文稿 1912.6-1920.11 (Mao Zedong's Early Manuscripts 1912.6-1920.11), edited by Zhonggong zhongyang wenxian yanjiushi 中共中央文獻研究室 and Zhonggong Hunan sheng wei “Mao Zedong zaoqi wengao” bianjizu 中共湖南省委 “毛澤東早期文稿” 編輯組 (Changsha: Hunan chubanshe, 1990), p. 639.

${ }^{110}$ See, for example, Antionino Raffone, Angela Tagini, and Narayanan Srinivasan, "Mindfulness and the Cognitive Neuroscience of Attention and Awareness," Zygon: Journal of Religion and Science 45:3 (2010): pp. 627-646; Zhou Changle 周昌樂, “Cong dangdai naokexue kan chanding zhuangtai dacheng de kenengxing jiqi yiyi 從當代腦科學看禪定狀 態達成的可能性及其意義 (Looking at the Probability and Meaning of Attaining the State of Meditative Concentration From the Perspective of Contemporary Brain Science)," Hangzhou shifan daxue xuebao [shehui kexue ban] 3:5 (2010): pp. 17-23. 
dramatic transformation of the scientific world. ${ }^{111}$ Something else, however, had changed as well. Although Yogācāra was not the only pillar for Tan's thought in EOB, along with other theories of mind, it was an important one; while Tan tried to show how Yogācāra and other theories of mental functioning cohered with one another, Taixu (who was a great admirer of $\mathrm{EOB}^{112}$ ) worked from the perspective of Yogācāra to identify deficiencies in scientific theories. By this time, it was not only the scientific environment that had been alteredChina's religious landscape had been shaken by the new anti-religious trends of the May Fourth generation.

In both historical contexts, however, Yogācāra served an important function in the broader Buddhist engagement with Western science, religion, and philosophy. Therefore, while the specific uses to which Tan put Yogācāra did not endure, his juxtaposition of it alongside both traditional ideas and the products of modernity was a demonstration of its intellectual relevance that lasted well into the twentieth century.

\footnotetext{
${ }^{111}$ Hammerstrom, "Buddhists Discuss Science," p. 118.

112 Taixu 太虛, "Taixu zizhuan 太虛自傳 (An Autobiography of Taixu)," in Taixu dashi quanshu 太虛大師全書 (The Collected Works of Master Taixu) (CD-ROM), edited by
} Yinshun 印順, vol. 29 (Xinzhu: Caituan faren Yinshun wenjiao jijinhui, 2005 [1940]), 191. 